


\section{Online folyóirat}

Szerkesztette: VÁGÁNY Judit Bernadett, PhD - FENYVESI Éva, PhD

Borító: FLOW PR

Kiadja: Budapesti Gazdasági Egyetem, Kereskedelmi, Vendéglátóipari és Idegenforgalmi Kar, Közgazdasági és Üzleti Tudományok Tanszék

Felelős kiadó: FENYVESI Éva, PhD

a Közgazdasági és Üzleti Tudományok Tanszék vezetője

ISSN 2630-886X

2020. 


\title{
VÁLLALKOZÓI ELKÉPZELÉSEK ÉS AKTIVITÁS A BUDAPESTI GAZDASÁGI EGYETEM HALLGATÓI KÖRÉBEN - AZ ELMÚLT 10 ÉV VÁLTOZÁSAI
}

\author{
ENTREPRENEURIAL IDEAS AND ACTIVITY OF \\ STUDENTS AT THE BUDAPEST BUSINESS SCHOOL \\ OVER THE PAST TEN YEARS
}

FARKAS Szilveszter - S. GUBIK Andrea

Kulcsszavak: vállalkozás, vállalkozásoktatás, vállalkozói attitüd, felsőoktatás Keywords: business, entrepreneurship education, entrepreneurial attitude, higher education

JEL kód: $I 21, I 23$ 


\section{ÖSSZEFOGLALÓ}

A vállalkozások alapvetó szerepet játszanak a gazdasági-társadalmi fejlödésben. Több kutatás igazolta, hogy a fiatalok, elsösorban az egyetemet, föiskolát végzettek vállalkozásainak növekedési üteme nagyobb, mint az idösebb korosztály által indított vállalkozásoké. A fiatalok cégalapitásaik során inkább keresik az innovativ területeket, nagyobb hozzáadott értéket teremtenek. Az egyetemi hallgatók. karrier elképzelései és vállalkozási aktivitása mindezele miatt fontos kutatási téma.

A Global University Entrepreneurial Spirit Students' Survey (GUESSS) nemzetközi kutatási projek.t 2003 óta foglalkozile ezekekel a területek.kel. A kérdezésekre kétévente került sor, a legutóbbi 2018 ben történt, ekekor 54 országban 208.636 ballgató töltötte ki a kérdöivet, a magyar hallgatók 9.767 kitöltött kérdöinvel járultak hozzáa a kérdezés sikeréhez: Magyarország 2006-ban kapcsolódott be a programba, a Budapesti Gazdasági Egyetem (BGE) 2008 óta vesz résż az adatfelvételekben.

A BGE a magyar egyetemek közül az elsök közö̈t ismerte fel a vállalkozások és igy a vállalkozásoktatás jelentöségét. Számos olyan programot valósitott meg az elmúlt években, amelyek a ballgatókat közvetve, vagy közvetlenül támogatják a vállalkozásokkal összefüggö tudás megszerzésében, a vállalkozói elképzelések kidolgozásában és megvalósitásában (Team Academy, Collab - Üzleti terv egy bét alatt, StartLab).

A cikek a Budapesti Gazdasági Egyetem hallgatóinak vállalkozói hajlandóságában és vállalkozói aktivitásában az elmúlt 10 évben mutatkozó változásokat mutatja be, majd összefoglalja azokat a társadalmi-gazdasági változásokat és azokat az egyetemi kezdeményezéseket, amelyek az elemzett területekre hatást gyakorolnak. Az elemzéshez a GUESSS kutatás 5 adatbázisa (2008-2018 közötti adatfelvételek) adja az inputot.

\section{SUMMARY}

Entrepreneurship plays a fundamental role in economic and social development. Several studies have shown that enterprises started by young people, especially university graduates, have a higher growth rate than firms ran by people belonging to older age groups. Young people are more likely to look for innovative areas and can create more added value. Therefore the university students' career ideas and entrepreneurial activity is an important research topic.

The Global University Entrepreneurial Spirit Students' Survey (GUESSS) project has been surveying these topics since 2003. The surveys were conducted every two years, the latest in 2018, when 208,636 students completed the questionnaire in 54 countries, Hungarian students contributed to the success of the inquiry with 9,667 completed surveys. Hungary joined the program in 2006, and Budapest Business School participated in all surveys.

Budapest Business School was one of the first universities in Hungary to recognize the importance of entrepreneurship, and thus the importance of entrepreneurship education. It has implemented a number of programs in recent years that directly or indirectly support students in acquiring business-related knowledge, in developing and implementing entrepreneurial ideas (Team Academy, Collab - Business plan during a week, StartLab).

The article describes changes in the entrepreneurial spirit and entrepreneurial activity of students at the Budapest Business School over the last 10 years, and then summarizes the socio-economic changes and 
university initiatives that have an impact on the areas analysed. The input to the analysis is provided by the 5 databases of the GUESSS research (data from 2008-2018).

\section{BEVEZETÉS}

A vállalkozásoktatás jelentőségével már évek óta tisztában vagyunk, ennek ellenére csak nagyon kis lépéseket tesz a felsőoktatás a hallgatók vállalkozói kompetenciáinak fejlesztése, hajlandóságuk és aktivitásuk fokozása terén. Ennek több oka van. Számos olyan képzési terület van, amely közvetlen módon nem foglalkozik a gazdasággal, az üzleti élettel (pl. orvosképzés). Az üzleti képzésben ugyan szerepeltek korábban is vállalkozási ismeretek, üzleti tervezés kurzusok, azonban ezek elszigetelt kísérletek maradtak, hiszen az oktatók tudása és tapasztalata nem kapcsolódott az induló vállalkozásokhoz, az intézményekben hiányzott az az infrastruktúra, amely teret adott volna a hallgatói ötletek kivitelezésének. Az elmúlt másfél évtizedben jelentős változás történt, megjelentek a nemzetközi tapasztalatokra építő hallgatói vállalkozásokat támogató megoldások (pl. Team Academy), a felsőoktatási intézmények és a vállalatok együttműködésében szerepet kaptak a vállalkozói ötleteket felkaroló projektek, pályázati támogatással inkubátor lehetőségek teremtődtek a hallgatók és természetesen az oktatók számára is, erősítve az egyetemi spin-off vállalkozások létrejöttét.

A felsőoktatásban lévő, vagy onnan kikerülő hallgatók vállalkozóvá válása nagyon kedvező a vállalkozói szektor szempontjából. A felsőfokú végzettséggel rendelkezők magasabb vállalkozói hajlandóságot mutatnak (Schot et al., 2015), növekedésorientáltabbak (Schrör, 2006), nagyobb arányban hozzák létre vállalkozásaikat magasabb hozzáadott értéket előállító ágazatokban (pl. high-tech iparágak), magasabb alaptőkével alapítják meg vállalkozásukat, mint a végzettséggel nem rendelkezők (Richert, Schiller, 1994, hivatkozza: Lüthje, Franke, 2002).

A Budapesti Gazdasági Egyetem 2008 óta résztvevője a GUESSS nemzetközi kutatási projektnek, amely az egyetemi hallgatók vállalkozási szándékát meghatározó tényezők feltárásával foglalkozik. Eddig öt felmérés kérdőíveit töltötték ki a hallgatók, ezért megkíséreljük összefoglalni a 2008 és 2018 közötti változásokat, és összehasonlítjuk azokat a magyarországi tendenciákkal.

A cikk a legfontosabb szakirodalmak áttekintése után arra vállalkozik, hogy a Budapesti Gazdasági Egyetem hallgatóinak vállalkozói hajlandóságában és vállalkozói aktivitásában az elmúlt 10 évben mutatkozó változásokat bemutassa. Ezt követően ismertetjük az egyetem által nyújtott szolgáltatások és az egyetemi vállalkozói légkör hallgatók általi megítélésében történt időbeli elmozdulásokat, majd összefoglaljuk azokat a társadalmigazdasági változásokat és azokat az egyetemi kezdeményezéseket, amelyek az elemzett területekre hatást gyakorolnak. A munka során a GUESSS kutatás 5 adatbázisát (20082018 közötti adatfelvételek) használjuk fel. 


\section{SZAKIRODALOM FELDOLGOZÁS}

A szakirodalomban nincs egyetértés arra vonatkozóan, hogy hogyan lehet leginkább sikeresen beavatkozni a vállalkozói elképzelések bátorítása terén. A jelenleg uralkodó megközelítés szerint komplex beavatkozásra van szükség, az elszigetelt eszközökkel szemben inkább a vállalkozói ökoszisztéma kialakítása a követendő cél.

Az egyre inkább elterjedő vállalkozói ökoszisztéma fogalom (Isenberg, 2011) a biológiából származik, és jól kifejezi a környezet jelentőségét és az összetett rendszerek működési sajátosságait, kapcsolatot teremtve az egyes tényezők és elemek között. Az ökoszisztéma elemeinek vizsgálata, hatékonyságuk értékelése lehetőséget adhat az okszerú beavatkozásra, a működési zavarokat okozó tényezők megváltoztatására, azaz szakpolitikai ajánlások megfogalmazására (Szerb, 2017).

„A vállalkozói ökoszisztéma olyan egymással összeköttetésben, kapcsolatban, interakcióban álló vállalkozó szemléletű egyének, szervezetek (pl.: vállalatok, kockázati tőkealapok, bankok), intézmények (egyetemek, állami ügynökségek), koncentrációja, melyben vállalkozásspecifikus folyamatok vannak jelen (új, magas növekedési potenciájú vállalkozások születésének magas foka, magas likvidációs ráta, sorozatvállalkozók, sikeres vállalkozók magas előfordulása), s melyet formális és informális folyamatok működtetnek, kormányoznak.” (Kuti, Bedő, 2016, 45).

A felsőoktatási intézmények a vállalkozói ökoszisztémák meghatározó elemei. E mellett azonban maguk is egy sajátos ökoszisztémát alkotnak, amelynek jellege hatást gyakorol a hallgatók vélekedésére és döntéseire. A felsőoktatási intézmények fontos feladata, hogy olyan légkört teremtsenek, olyan szolgáltatásokat és képzési struktúrát alakítsanak ki, amelyekkel a vállalkozások iránt nyitott hallgatók vállalkozói ambícióit serkentik, vállalkozói aktivitásukat ösztönzik. A vállalkozói ökoszisztéma elemeiből ezért némelyeket a felsőoktatási intézmények falain belül is meg kell találnunk, ezek együttesével pedig leírhatjuk a hallgatói vállalkozói ökoszisztéma modelljét. Ebben a következőket tekintjük kulcselemeknek:

- a hallgatók vállalkozási szándékát (igényét),

- a vállalkozások alapítását, indulását segítő egyetemi infrastruktúra meglétét (internet, könyvtár, termek, etc.),

- a vállalkozói kultúra beépülését az egyetemi kultúrába,

- formális intézmények (pl. vállalkozói klub), hálózatok (vállalati kapcsolatok, alumni),

- az ötletek támogatása, a hallgatói vállalkozási tevékenységének irányítása,

- pénzügyi háttér (üzleti angyalok, üzleti tervkészítési pénzdijas verseny),

- tehetség,

- tudás (tantervi és azokon kívüli vállalkozásokkal kapcsolatos kurzusok)

- támogató szolgáltatások (pl. inkubáció). (Gubik, Farkas, 2017) 
A felsőoktatási intézmények vállalkozásösztönzés terén játszott szerepére irányuló kutatások jelentôs része a képzési kínálatra fókuszál. Arra, hogy milyen tárgyakat és milyen oktatási megoldások formájában közvetítsenek az egyetemek a hallgatók felé. Más kutatások pedig azokra a szolgáltatásokra összpontosítanak, amelyek segíthetik a hallgatókat saját vállalkozásaik beindításában Ez a támogatás sokféle formában valósulhat meg; mentor program, inkubációs segítség, vagy akár közvetlen pénzügyi támogatás keretében (Rideout, Gray, 2013).

A GUESSS projektnek is fontos eleme a felsőoktatási intézmények hatásának értékelése. Azonban a 2008-as részletes kérdések 2018-ra általános kérdésekké alakultak át így csak általánosságban tehetünk megállapításokat a felsőoktatási vállalkozási ökoszisztéma működéséről és hatékonyságáról.

Gubik (2013) multinomiális logisztikus regresszió alkalmazásával a családi vállalkozói háttér, a nem és a kor változók mellett az igénybe vett kurzusok és szolgáltatások szignifikáns hatást mutatta ki a vállalkozásindítási szándékra és aktivitásra. A kurzusok és szolgáltatások kihasználtsága és a vállalkozásindítási elképzelések közötti pozitív irányú összefüggés a képzési területet kontroll alatt tartása esetén is fennállt.

Moriss és munkatársai a 2011-es GUESS adatbázisán vizsgálták 25 ország, 282 egyetemének vállalkozói szándékot mutató 31.927 hallgatói válasza alapján a felsőoktatási környezet hatását. Regresszión alapuló eredményeik alátámasztják, hogy a tantervi programok pozitív hatást gyakorolnak a hallgatók vállalkozói szándékára, emellett a speciális vállalkozói ismeretek oktatása és a pénzügyi támogatás is ösztönzi a vállalkozói szándékot, ugyanakkor a korábbi vállalkozói tapasztalat negatív hatással van rá.

A kutatás eredményei egy további szempontra hívják fel a figyelmet, mégpedig arra, hogy a pénzügyi támogatás önmagában nem biztosítja a hallgatói vállalkozások hosszabb távú fennmaradását, fejlődését. A szerzők másik fontos megállapítása, hogy az egyetemi évek előtt szerzett vállalkozói tapasztalat nem hasznosítható egyértelműen a felsőoktatási hallgatói vállalkozási ökoszisztéma oktatási alrendszerének múködtetése során (Moriss et al. 2017).

A kutatások alapján feltételezhetjük, hogy a felsőoktatási intézmények oktatási programjai (kötelező és választható vállalkozási tárgyi kurzusok) hatással vannak a hallgatók vállalkozási szándékára, az intézmény vállalkozást segítő ökoszisztémája pedig közvetlenül a vállalkozói cselekvést segíti. Ugyanakkor nem elegendő a szolgáltatások elérhetővé tétele, a hallgatók igényét is fel kell ébreszteni ezek igénybevételére (Gubik, 2013).

\section{ANYAG ÉS MÓDSZER}

A GUESSS (Global University Entrepreneurial Spirit Students' Survey) a hallgatók vállalkozásindítással kapcsolatos elképzeléseit és a vállalkozási tevékenységét kérdőív segítségével vizsgálja. (A kutatási projekt honlapja: http://guesssurvey.org. A kutatás módszertani kérdéseiről lásd: Farkas, Gubik (2013).) Elemzi a hallgatók karrierelképzeléseit a diploma megszerzése után és néhány év elteltével, a vállalkozói 
terveket, a működő hallgatói vállalkozásokat és a családi vállalkozói hátteret. A kérdőívek évről évre visszatérő kérdései lehetőséget adnak az időbeli változások nyomon követésére és a legfontosabb trendek felismerésére (Farkas, Gubik 2013). Az időbeli összehasonlítás azonban néhány esetben korlátozott, mivel a kérdőívek tartalma, a kérdések néhol változtak. Ezen felül azt is figyelembe kell venni az eredmények értékelésekor, hogy nem paneladatokon végezhetôk el az elemzések, csupán trendelemzés történik a GUESSS kutatás keretein belül.

A GUESSS adatfelvételekre általában kétévente kerül sor. Az első lekérdezés 2003-ban történt, akkor még csak két ország részvételével, 2018-ban, a 7. felmérésben pedig már 54 ország vett részt. Magyarország 2006-ban csatlakozott a kutatáshoz, így már 6 adatfelvétel adatbázisa áll rendelkezésre, amelyeknek köszönhetően 12 év változásait elemezhetjük a kérdőív visszatérő és egyező kérdései segítségével országos szinten.

Jelen cikkben a Budapesti Gazdasági Egyetem válaszadóira fókuszálunk. Az elemzett minták legfontosabb adatait az 1. táblázat foglalja össze.

1. táblázat. Válaszadók jellemzői 2008-2018

\begin{tabular}{lcccrc}
\hline & $\mathbf{2 0 0 8}$ & $\mathbf{2 0 1 1}$ & $\mathbf{2 0 1 3}$ & $\mathbf{2 0 1 6}$ & $\mathbf{2 0 1 8}$ \\
\hline $\begin{array}{l}\text { Beérkezett válaszok } \\
\text { száma }\end{array}$ & 324 & 622 & 1630 & 1289 & 975 \\
Nem (\%) & & & & & \\
Férfi & 30,2 & 28,8 & 32,1 & 65,7 & 33,0 \\
Nő & 69,8 & 71,2 & 67,9 & 34,3 & 67,0 \\
Képzési szint (\%) & & & & & \\
BSc (alapszakok)* & 93,8 & 98,6 & 89,5 & 79,3 & 79,4 \\
MSc (mesterszakok)* & 6,2 & 1,4 & 9,4 & 9,0 & 5,6 \\
Egyéb (PhD, & - & - & 1,1 & 11,7 & 15,0 \\
Posztdoktori) & & & & & \\
\hline
\end{tabular}

* A magyar felsôoktatási rendszer egyik legjelentôsebb átalakitása 2006-hoz köthetô. A bolognai rendszer bevezetése és a hagyományos rendszer együttélése jelentôs bonyodalmat okozott a válaszadás során az alap-és mesterszakos besorolásban, illetve a gazdasági/ ïleti képzés társadalomtudományi besorolásakor 2008-ban.

Forrás: GUESSS adatfelvételek. 2008-2018, saját számítások.

\section{EREDMÉNYEK}

A Budapesti Gazdasági Egyetem sajátos helyzetét az adja, hogy képzési szerkezetében többségben vannak az üzletei képzési területek az összes képzési szinten. Ez azt jelenti, hogy minden képzési formájában megjelennek olyan tárgyak, amelyek a vállalkozások működtetésével kapcsolatos kompetenciákat fejlesztik. Ezért is érdekes, hogy a hallgatók közül mennyien vállalkozók és mennyien tervezik saját vállalkozás indítását a jövőben. Jelen cikkben az adatok bemutatásán túl az egyetemi környezet hallgatók általi értékelését is bemutatjuk, majd pedig az egyetem által nyújtott szolgáltatások közül mutatunk be egyet. 


\section{A Budapesti Gazdasági Egyetem hallgatóinak vállalkozói hajlandósága 2008-2018 között}

Az ismétlődő adatfelvételeknek köszönhetően lehetőség nyílt a vállalkozói hajlandóság időbeli alakulásának megfigyelésére. Az alábbi ábra a vállalkozást tervezők arányát mutatja az összes válaszadó százalékában.

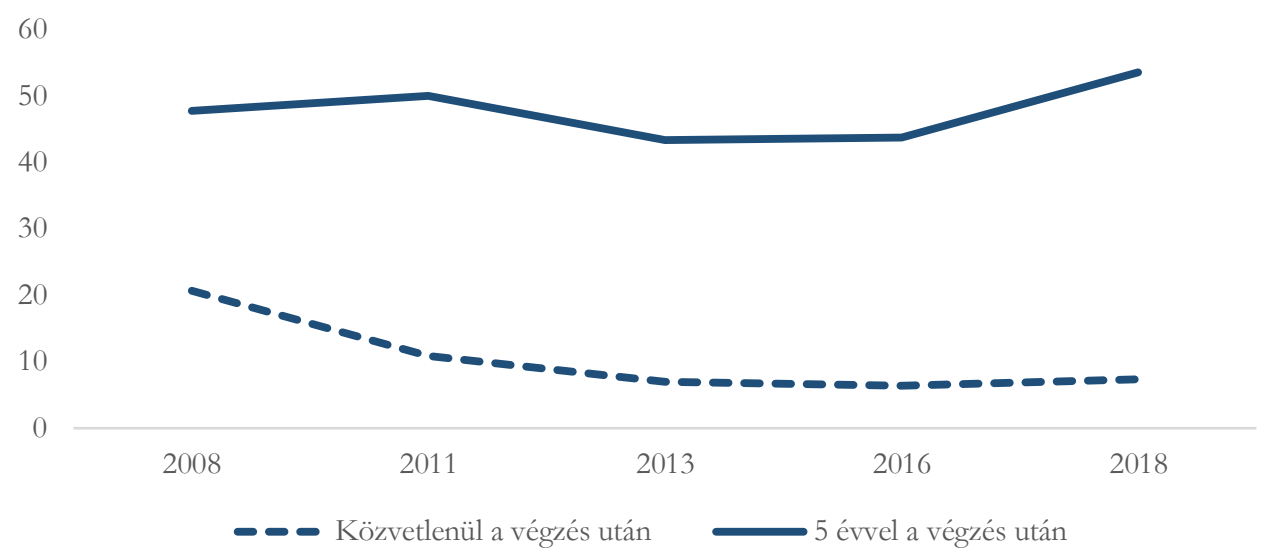

1. ábra. Vállalkozást tervezők aránya, BGE, 2008-2018 (százalék)

Forrás: GUESSS adatfelvételek. 2008-2018, saját sžerkesztés

A hallgatók karrier elképzelései közvetlenül a végzés után és a végzés után öt évvel jelentős különbséget mutatnak, a közvetlenül a végzést követően vállalkozást tervezők aránya messze elmarad a későbbi karriertervektől. A végzést követően vállalkozni szándékozók aránya jelentősen csökkent a vizsgált időszakban. Míg 2008-ban még a hallgatók 20,7 százaléka szeretett volna saját vállalkozásba fogni a diploma megszerzése után, 2018-ban már csak 7,4 százalék nyilatkozott így. A legalacsonyabb, 6,4 százalékos érték 2016-ban tapasztalható. Ezek vizsgálatára nem tértünk ki, a kérdőív nem tartalmazott ilyen jellegű kérdéseket, de úgy véljük, hogy a 2008-at követő csökkenés mögött a pénzügyi válság hatásait fedezhetők fel. E mellett generációs és munkaerőpiaci trendekből következô hatások is állhatnak a háttérben.

A közvetlenül a végzés után vállalkozói karrierben gondolkodók országos átlaga 2018 ban 6,3 százalék (míg a válaszadó BGE hallgatók átlaga 7,4 százalék), de a képzési területek megkérdezések szerinti eltérései miatt az adatokat a gazdasági/üzleti és közgazdasági területeken lehet csak összevetni. Az előbbiben az országos átlag 8,9 százalék, a BGE hallgatóinak átlaga ezt meghaladó, 9,6 százalék, az utóbbiban, a közgazdasági területen pedig a 8,2 százalékos országos átlag mellett 6,3 százalékos adatot találunk a BGE hallgatói között.

Ami az öt évvel a végzést követő vállalkozási szándékot illeti, ott töretlen optimizmus jellemzi a hallgatókat. A 2008-as 47,8 százalékról 2011-re 50 százalékra nőtt az érték, majd 
a 2013-as és 2016-os alacsonyabb érték után 2018-ban ismét kiugróan magas, csaknem 54 százalékos vállalkozói hajlandóságot mértünk a BGE hallgatói körében.

2018-ban a vállalkozást tervezők országos átlaga 40,7 százalék. Ezen belül a gazdasági/üzleti, területen 53,6 százalék, míg a BGE ugyanezen adata 56,7; közgazdasági területen pedig 49,8 százalék, míg a BGE ugyanezen a képzési területen lévő hallgatói esetén 54 százalék szeretne vállalkozni a végzést követően.

A karrier elképzelések jellegzetes eltérést mutatnak nemek, kor, családi vállalkozói háttér és képzési terület szerint is. Ezek közül az eltérések közül most a nemek és a családi vállalkozói háttér szerinti eltérések alakulását mutatjuk meg a Budapesti Gazdasági Egyetem hallgatói esetében.

A férfi hallgatók nagyobb arányban szeretnének vállalkozni, mint a nők, ez minden évben igaz volt, a különbség azonban 2008-at követően jelentősebbé vált (2. ábra).

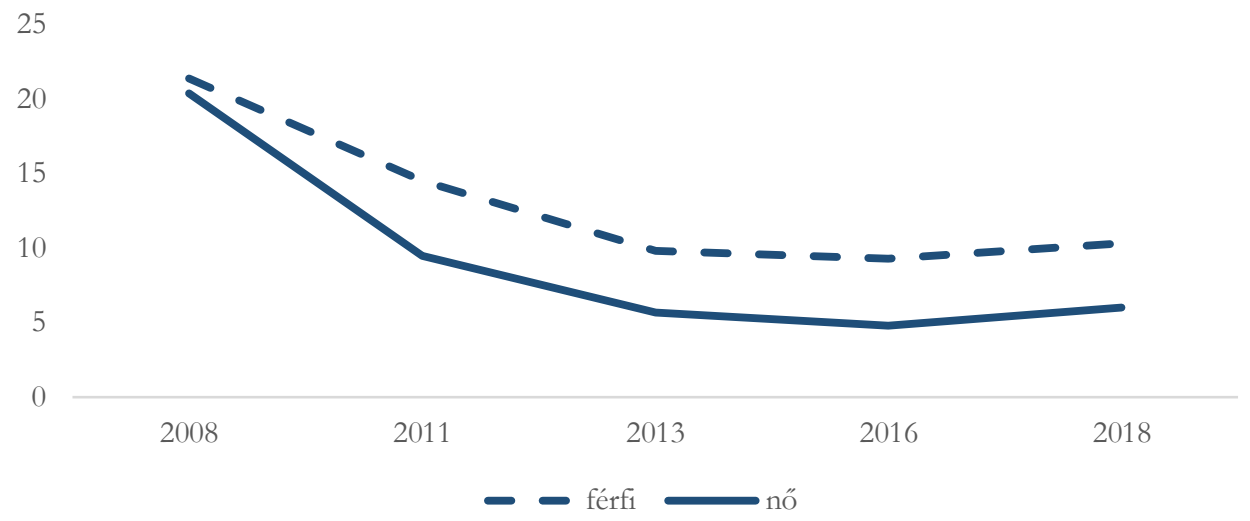

\section{2. ábra. Végzés után vállalkozói karriert tervezők aránya nemenként, BGE hallgatók} (százalék)

Forrás: GUESSS adatfelvételek 2008-2018, saját szerkesztés

A családi vállalkozói tapasztalatok növelik a vállalkozói elképzelések valószínűségét. Az alábbi, 2018-as helyzetet bemutató ábra jól mutatja, hogy a vállalkozói háttérrel (szülők önfoglalkoztatók vagy többségi tulajdonosai egy vállalkozásnak) rendelkező hallgatók között nagyobb a vállalkozást tervezők aránya (3. ábra). 


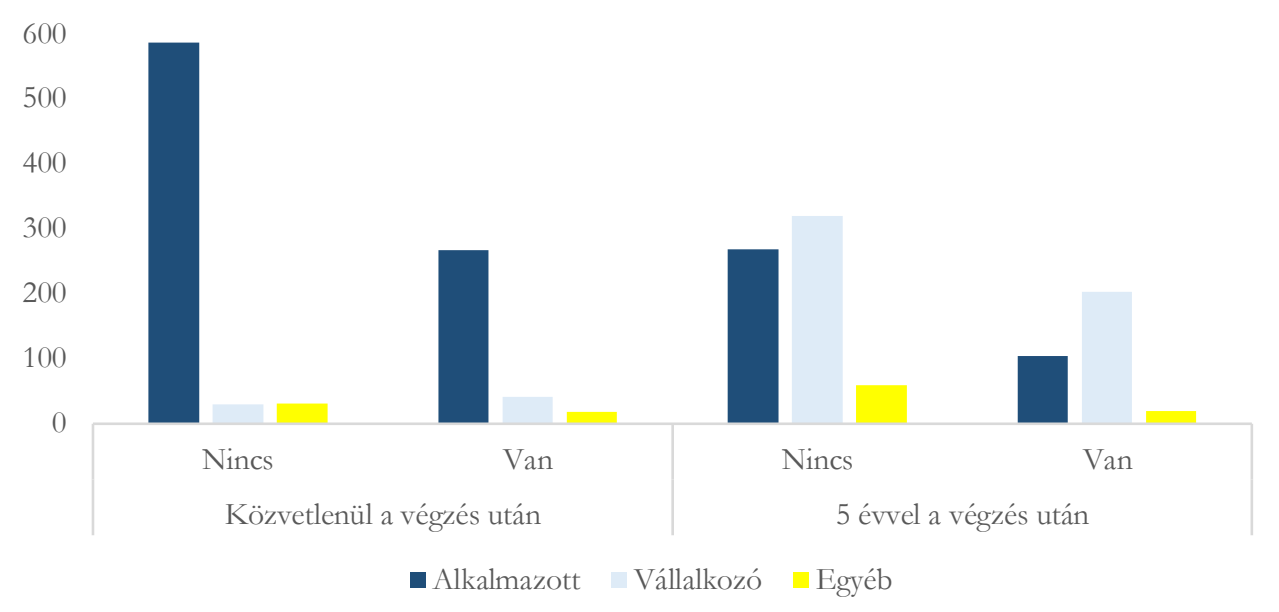

\section{3. ábra. Karriertervek családi vállalkozó háttér szerint, BGE, 2018 (hallgatók száma)}

Megjegyzés: Nincs - nincs önfoglalkoztató vagy többségi tulajdonos szüló, V an - önfoglalkoztató vagy többségi tulajdonos s₹ülö a családban

Forrás: GUESSS adatfelvételek 2008-2018, saját szerkesztés

Az otthoni tapasztalatok, a vállalkozói lét megtapasztalása tehát ösztönzőleg hat a vállalkozási elképzelésekere.

\section{A Budapesti Gazdasági Egyetem hallgatóinak vállalkozói aktivitása 2008-2018 között}

A vállalkozó hallgatók aránya meglehetősen alacsony volt 2008-ban és további csökkenést mutat 2008-2011 között, amelynek oka részben a pénzügyi válság kibontakozása lehet. Ezt követően a statisztikák jelentős növekedést mutatnak 2016-ig. A 2018-as felmérés a hallgatói vállalkozói aktivitás 2 százalékpontos csökkenéséről ad számot. Az aktív vállalkozók országos mintában tapasztalható aránya 2018-ban 5,1 százalék volt. Ettől magasabb az üzleti/gazdasági képzési terület statisztikája, ami 2018 ban 7,7 százalék.

A 2011 és 2016 közötti növekedés magyarázatára a kérdőív nem tért ki, de úgy véljük, hogy a pénzügyi válság utáni megtorpanást követő fellendülés a hallgatókra éppúgy hatással volt, mint a gazdaságra. A hallgatói vállalkozások jelentős része önfoglalkoztatás (83,7 százalék 2018-ban), ráadásul olyan területeken (pénzügyi szolgáltatások, kereskedelem), amely arra utalhat, hogy a vállalkozó hallgatók egy része pótlólagos pénzügyi forrásokat biztosít magának tanulmányai idejére.

A 2018-as csökkenés esetén pedig fontos magyarázó elem lehet a vállalati szektor elszívó hatása. A vállalatok ugyanis növekvő számban kínálnak ,gyakornoki” pozíciókat, ezek között nem ritka a 40 órás foglalkoztatás sem, amely az önfoglalkoztatási lehetőségek kihasználásnak visszaszorulását eredményezte (4. ábra). 


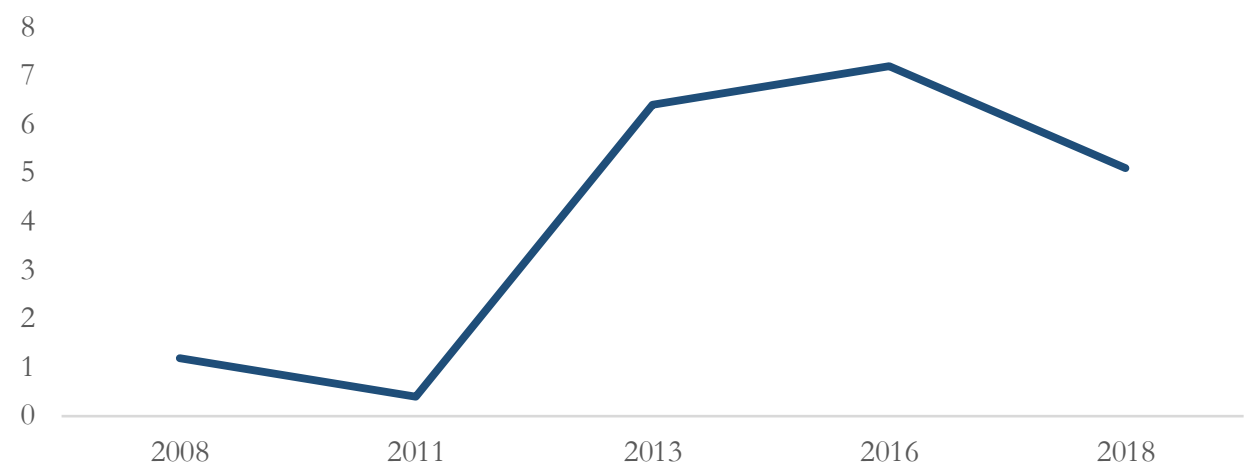

4. ábra. Aktív vállalkozók aránya, BGE, 2008-2018 (százalék)

Forrás: GUESSS adatfelvételek, 2008-2018, saját szerkesztés

A vállalkozó hallgatók között szignifikáns eltérés adódik nemek szerint. A férfiak vállalkozói aktivitása minden vizsgált időszakban magasabb, de az olló 2011 utáni jelentős növekedése mindenképpen említést érdemel. Ebben szerepet játszhat a férfi hallgatók magas kockázatvállalási hajlandósága, aktívabb lehetőség keresése és azok kihasználása.

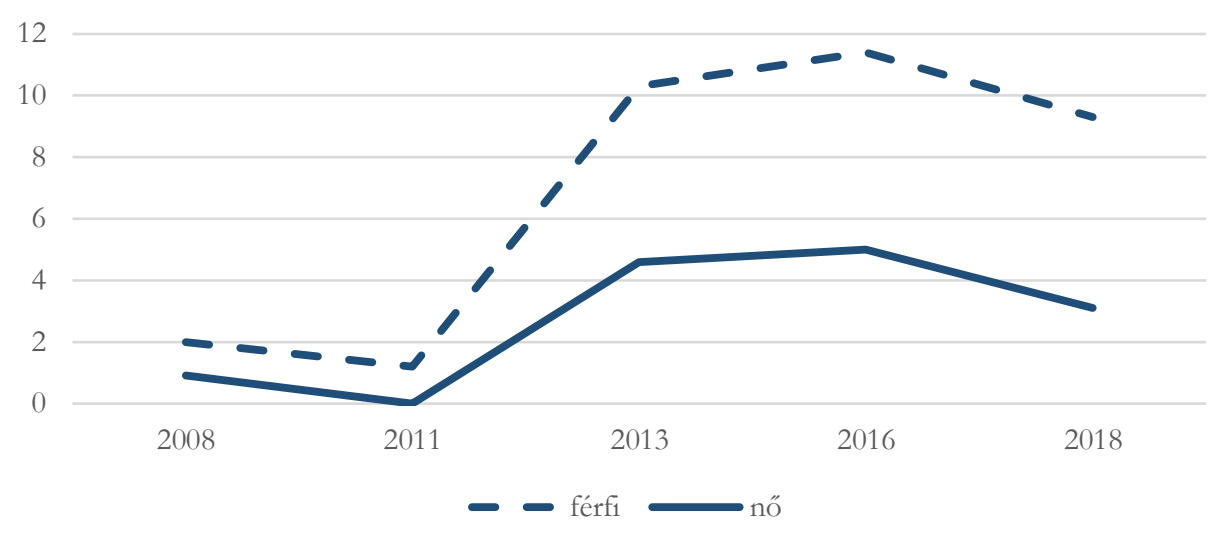

5. ábra. Aktív vállalkozók arányának alakulása nemek szerint, BGE, 2008-2018 (százalék) Forrás: GUESSS adatfelvételek. 2008-2018, saját sžerkesztés

A tényleges vállalkozói aktivitásnál nem volt megfigyelhetô a családi vállalkozói tapasztalatok meghatározó szerepe.

\section{Az intézményi környezet értékelése}

Az egyetem által nyújtott szolgáltatások, valamit a teremtett vállalkozói klíma mérésére eltérő kérdések adódtak az egyes kérdôívekben. A szolgáltatásokat illetően a legrészletesebb elemzésre a 2011 -es adatbázis adott lehetőséget. Ennek eredményeiről lásd Gubik, Farkas (2014). 2013-tól a kérdőívek a felsőoktatási intézmények vállalkozói 
környezeti hatásával és az intézmények által nyújtott szolgáltatások hallgatói értékelésével kapcsolatban általános kérdéseket tartalmaznak, a kurzusok, a nem tantervi szolgáltatások részletező értékelésére vonatkozó részletes kérdések elmaradtak.

Erre a két visszatérő kérdés elemzésére tudunk most kitérni a 2011 és 2018 közötti időszakra vonatkozóan. Az első az egyetemek által nyújtott és a hallgatók által igénybe vett kurzusok és szolgáltatások hallgatói megítélésére vonatkozik. A Budapesti Gazdasági Egyetem hallgatóinak véleményét a 2. táblázat tartalmazza. A 2011-et követően csaknem valamennyi kérdés esetén visszaesés figyelhető meg, 2018-ban azonban kiemelkedően magas a hallgatók által adott pontszámok átlaga.

2. táblázat. Az egyetem által nyújtott szolgáltatások értékelése, BGE, 2011-2018

\begin{tabular}{|c|c|c|c|c|}
\hline Az Egyetem által nyújtott szolgáltatás ... & 2011 & 2013 & 2016 & 2018 \\
\hline $\begin{array}{l}\text { növelte a vállalkozói attitűdök, értékek és } \\
\text { motivációk megértését. }\end{array}$ & 4,49 & 4,36 & 4,25 & 4,64 \\
\hline $\begin{array}{l}\text { növelte a vállalkozásindításhoz szükséges } \\
\text { tevékenységek megértését. }\end{array}$ & 4,77 & 4,53 & 4,46 & 4,80 \\
\hline $\begin{array}{l}\text { fejlesztette a vállalkozás indítással } \\
\text { kapcsolatos gyakorlati ismereteimet. }\end{array}$ & 4,64 & 4,52 & 4,35 & 4,67 \\
\hline fejlesztette kapcsolatépítő képességemet. & 4,61 & 4,54 & 4,35 & 4,60 \\
\hline $\begin{array}{l}\text { fejlesztette a lehetőség felismerő } \\
\text { képességemet. }\end{array}$ & 4,62 & 4,70 & 4,47 & 4,69 \\
\hline
\end{tabular}

Megjegyzés: az értékelés 1-7 Likert skálán történt (1=egyáltalán nem értek egyet, $7=$ teljesen egyetértek).

Forrás: GUESSS adatfelvételek 2011-2018, saját szerkesztés

Az egyetemi vállalkozói környezet megítélése esetén is hasonló tendenciák figyelhetők meg, a 2018-as értékek itt is kiemelkednek (3. táblázat). A kiemelkedő értékek talán magyarázhatók a gyakorlatorientált képzési stratégia következetes megvalósításával, a vállalati esettanulmányokra építő kurzusok számnak gyarapodásával és a vállalatok részvételével az oktatásban (pl. speciális kurzusok meghirdetése).

3. táblázat. Az egyetemi környezet értékelése, BGE, 2011-2018

\begin{tabular}{|c|c|c|c|c|}
\hline & 2011 & 2013 & 2016 & 2018 \\
\hline $\begin{array}{l}\text { Az egyetemi/főiskolai légkör új üzleti ötletek } \\
\text { kidolgozására ösztönöz. }\end{array}$ & n.a. & 3,87 & 3,72 & 4,17 \\
\hline $\begin{array}{l}\text { Az egyetem/főiskola a vállalkozóvá váláshoz } \\
\text { kedvező környezettel rendelkezik }\end{array}$ & 4,02 & 4,17 & 4,00 & 4,48 \\
\hline $\begin{array}{l}\text { Az egyetemen/főiskolán a hallgatókat } \\
\text { ösztönzik a vállalkozói tevékenység } \\
\text { folytatására }\end{array}$ & n.a. & 4,12 & 3,99 & 4,64 \\
\hline
\end{tabular}


A szolgáltatások és a klíma megítélésében nagy eltéréseket találunk a szerint, hogy a hallgatók milyen karrierelképzelésekkel rendelkeznek. Akiknek vállalkozói ambícióik vannak, magasabbra értékelik a nyújtott szolgáltatásokat és általában az egyetemi erőfeszítéseket, mint azok, akik erről nem számoltak be. A 4. táblázat csak a 2018-as adatokat mutatja be, de kiválóan szemlélteti, hogy nem elegendő a szolgáltatások rendelkezésre állásának a biztosítása, szükségesek olyan programok, tevékenységek, amelyek a hallgatók figyelmét rá tudják ezekre irányítani.

4. táblázat. Az egyetem által nyújtott szolgáltatások megítélése karrierelképzelések szerint, BGE, 2018

\begin{tabular}{lccc}
\hline Az Egyetem által nyújtott szolgáltatás ... & Alkalmazott & Vállalkozó & Egyéb \\
\hline $\begin{array}{l}\text { növelte a vállalkozói attitűdök, értékek és } \\
\text { motivációk megértését. }\end{array}$ & 4,63 & 4,68 & 4,65 \\
$\begin{array}{l}\text { növelte a vállalkozásindításhoz szükséges } \\
\text { tevékenységek megértését. }\end{array}$ & 4,81 & 4,76 & 4,78 \\
$\begin{array}{l}\text { fejlesztette a vállalkozás indítással kapcsolatos } \\
\text { gyakorlati ismereteimet. }\end{array}$ & 4,66 & 4,69 & 4,84 \\
fejlesztette kapcsolatépítő képességemet. & 4,57 & 4,69 & 4,86 \\
fejlesztette a lehetőség felismerő képességemet. & 4,67 & 4,93 & 4,71 \\
\hline
\end{tabular}

Forrás: 2018-as GUESSS adatfelvétel, saját szerkesz̨tés

Az egyetemi vállalkozói környezet megítélése általában a vállalkozást tervező hallgatók körében pozitívabb, mint az alkalmazotti vagy egyéb karriert tervezők között (5. táblázat). Az egyetem vállalkozás ösztönző környezetét mindhárom karrier mintát választó hallgatói csoport közel azonos értékkel minősítette, ami fontos visszaigazolása az intézményi erőfeszítéseknek.

5. táblázat: Az egyetemi vállalkozói környezet megítélése karrierelképzelések szerint, BGE, 2018

\begin{tabular}{lccc}
\hline & Alkalmazott & Vállalkozó & Egyéb \\
\hline $\begin{array}{l}\text { Az egyetem atmoszférája új üzleti ötletek } \\
\text { kidolgozására ösztönöz. }\end{array}$ & 4,13 & 4,50 & 4,35 \\
$\begin{array}{l}\text { Az egyetem/fóiskola a vállalkozóvá váláshoz } \\
\text { kedvező környezettel rendelkezik. }\end{array}$ & 4,47 & 4,63 & 4,41 \\
$\begin{array}{l}\text { Az egyetemen/fóiskolán a hallgatókat ösztönzik } \\
\text { vállalkozói tevékenység folytatására. }\end{array}$ & 4,64 & 4,65 & 4,59 \\
\hline
\end{tabular}

Forrás: 2018-as GUESSS adatfelvétel, saját szerkesz̨tés

\section{A trendek legfontosabb hajtóerői}

\section{Gazdasági: válság, kilátások, kényszervállalkozások, anyagi erőforrások}

A vállalkozási hajlandóság és a vállalkozási aktivitás fontos meghatározója a gazdasági környezet. A hallgatók bemutatott vállalkozási statisztikái (elsősorban annak időbeli ingadozásai) összefüggenek a munkaerőpiac állapotával és általában véve a gazdaság 
teljesítőképességével. A legjobban működő felsőoktatási ökoszisztémának sincs esélye, ha a vállalkozóvá válás általános, gazdasági-társadalmi keretrendszere nem múködik megfelelően, vagy ha vállalkozónak lenni nem versenyképes elképzelés az alkalmazotti léttel összevetve a szabályozási környezet sajátosságai miatt (pl. adminisztrációs költségek, adórendszer).

\section{Változó generációk, változó motivációk}

$\mathrm{Az}$ is fontos szempont, hogy kikre kell szabni a szolgáltatásokat. A szakirodalom felhívja a figyelmet arra, hogy az iskolapadba ülő új generáció, az ún. Z generáció, számos olyan jellegzetességet mutat, amelyek meghatározók a vállalkozási kérdésekkel kapcsolatban. Internet-alapú, információdús, vizualizációval teli életmódjuk miatt a sebesség életük meghatározó részévé vált a pontosság és az elmélyültség rovására (Lerf, 2014). Túlzott magabiztosság és önbizalom jellemzi őket, amely gyorsan beteljesülő karrierelvárásokkal, és alacsony fokú elköteleződéssel jár együtt (Ferincz, Szabó, 2012). Tudatosabban törekszenek a munka és magánélet egyensúlyára (Tari, 2010).

Ugyan ez a magabiztosság és önbizalom elvezetheti őket a vállalkozói pályára, de ott olyan adminisztratív és szakmai jártasságra is szükségük van, amelyek elsajátítása időigényes (és esetleg kevésbé érdekes).

A kommunikáció gyorsasága, az információk megszerzésének egyszerűsége következtében azonnali megoldásokat, azonnali eredményeket várnak el, ami a vállalkozási folyamatban nem feltétlenül érvényesül. A kemény munka iránti elkötelezettség és a hosszú távú szemlélet hiánya a vállalkozások gyors kudarcát hozhatja, amennyiben az üzleti sikerek nem azonnal jelentkeznek (Gubik, Farkas 2016).

\section{Egyetemi környezet: oktatási megújulás, szolgáltatások}

A bemutatott generációs változások a tudásátadás módját is érdemben befolyásolják. Másképp kelthető fel az érdeklődésük (például több vizualizáció, nagyobb gyorsaság), másképpen tartható fenn (gamifikáció, gyakori visszajelzések stb.), mint ami az oktatás rendszerében eddig megszokott és elfogadott volt.

A felsőoktatás átalakulóban van, amelynek része a tananyagok és az oktatási megoldások átszabása, de a hallgatóknak nyújtott széles körű szolgáltatások kialakítása is.

\section{Egy sikeres vállalkozásfejlesztési ökoszisztéma - Team Academy szakirány}

A finn felsőoktatási rendszer innovatív - az OECD által díjazott - vállalkozásoktatási programja 1993 óta múködik a Jyväskylä-i JAMK University of Applied Sciences-en, Tiimiakatemia (Team Academy, TA) néven. Jelenleg a világ 8 országának 19 felsőoktatási intézményében működik, Magyarországon a Budapesti Gazdasági Egyetemen és a Debreceni Egyetemen. (http://www.tiimiakatemia.fi/en/) A TA képzési stratégiája a „learning by doing” vállalkozásoktatási módszer, amelynek sajátossága, hogy a hallgatók rendhagyó módszerekkel, a gyakorlati életben sajátítják el a vállalkozói készségeket. A hallgatók csoportjai eseti vagy folyamatos együttmúködési megállapodásokat kötnek a 
munkájukra igényt tartó vállalatokkal, így nem elméleti síkon modellezik, hanem a projekteken dolgozva valós üzleti környezetben tapasztalják meg mindazt, ami a diploma megszerzése után vár rájuk. A hallgatók a tudást nem a magyar oktatásra hagyományosan jellemző „frontális” módszerekkel szerzik meg, hanem az együtt végzett csapatmunka során, amelyben ún. team coach-ok támogatják őket.

A Team Academy a learning-by-doing módszerét alkalmazza a BGE Pénzügyi és Számviteli Karán a Gazdálkodási és menedzsment alapszak Team Academy (TA) szakirány/specializáció képzési programjában a vállalkozói készségek elsajátítására. A képzés honlapján elérhető információk szerint a 2012-es kezdés óta 129 hallgató vett részt a képzésben, több mint 50 projektet valósítottak meg 3000 coach által támogatott óra keretében, 300-nál több külső szakmai kapcsolat kialakításával. A nem Team Academy-n végzett gazdálkodási és menedzsment szakos hallgatók átlagosan 5 százaléka, ehhez képest a Team Academy végzettjeinek körülbelül 20 százaléka vállalkozó jelenleg (2019ben). A BGE Team Academy képzése lett 2018-ban az Európai Vállalkozásfejlesztési Díj nemzeti nyertese „befektetés a vállalkozói kompetenciák fejlesztésébe” kategóriában. A Díj célja az európai államokban megtalálni és elismerni a legkreatívabb és legsikeresebb vállalkozásösztönzési projekteket. (https://teamacademybudapest.hu/rolunk/).

A BGE Team Academy coach-ai 2014-ben végeztek egy vizsgálatot, amelyben felhasználták a GUESSS 2013-as kérdőív karrier elképzelésekre vonatkozó kérdéseit. Arra keresték a választ, hogy a TA és a nem TA hallgatók vállalkozási szándéka között milyen eltérések mutathatók ki. A legjelentősebb és egyben az elemzést készítők számára is a legnagyobb meglepetést a karrier választással kapcsolatos elképzelésekben megmutatkozó különbség okozta (Tasi, Zsigmond 2014). A Budapesti Gazdasági Egyetem hallgatóinak 83 százaléka alkalmazotti, 6 százaléka vállalkozói karriert képzelt el a tanulmányai végeztével. A TA hallgatóinak azonban mindössze 62 százaléka szeretett volna alkalmazottként elhelyezkedni, 29 százalék pedig vállalkozóként képzelte el a jövőjét (lásd 1. ábra). Az intézményi környezet vállalkozóvá válást ösztönző légköréről és a tanulmányok szerepéről feltett kérdésekre adott válaszokban nem volt a karrier elképzelések szerinti jelentős különbség (Tasi, Zsigmond 2014).

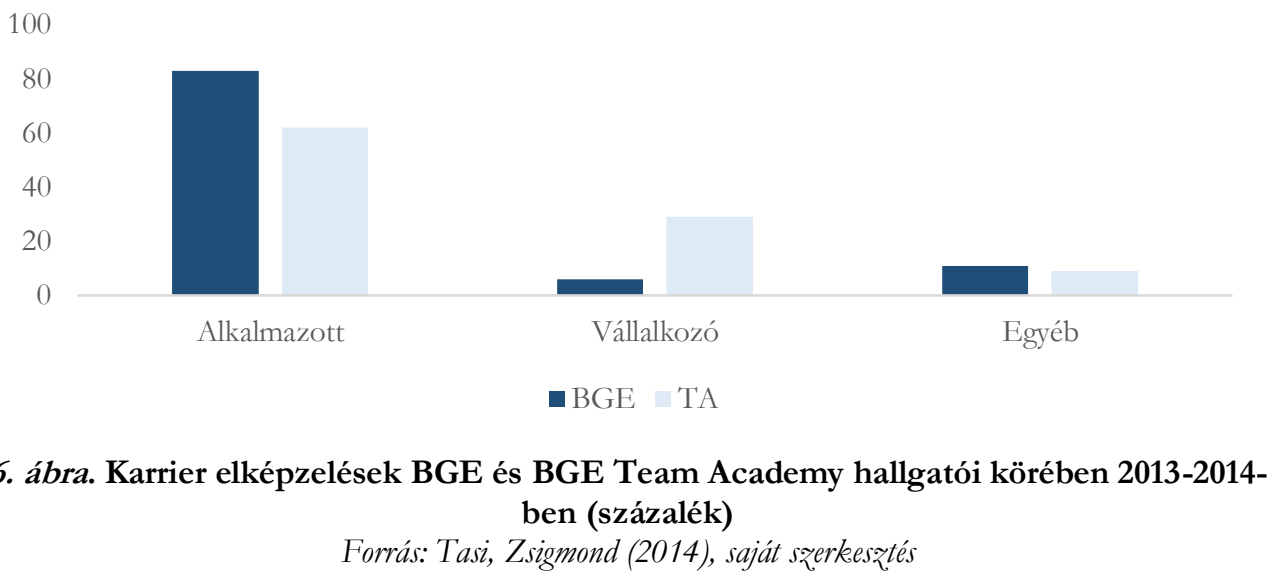




\section{KÖVETKEZTETÉSEK, JAVASLATOK}

A felsőoktatásban résztvevő fiatalok vállalkozóvá válásának egyik meghatározó szempontja, hogy milyen szolgáltatásokat nyújt intézményük és milyen vállalkozási klímát alakít ki.

Ennek fontos része a vállalkozással kapcsolatos kurzusok elérhetősége akár tantervi keretek között, vagy azon kívül. Ezek kihasználtsága eltérő a hallgatói vállalkozói tapasztalatok és elképzelések szerint, ezért központi kérdés az igény felkeltése a kurzusok iránt.

A fentiek mellett a meglévő kurzusok tartalmának átalakítása is vita tárgya. Tudjuk, hogy gyakorlatorientált, valós helyzeteket szimuláló oktatási megoldásokra van szükség, de az is nyilvánvaló, hogy ezek megteremtése számos feltétellel jár, kezdve a képzési és kimeneti követelmények rugalmassá tételétől az oktatók hagyományos, heti óraszám alapú teljesítmény értékelésének újragondolásáig.

Ugyanez igaz az egyéb szolgáltatások esetén is. A legelkötelezettebb felsőoktatási intézmények is küzdenek a hallgatói passzivitással, a legjobb programok is csak akkor lehetnek sikeresek, ha képesek az intézmények bevonzani a hallgatókat.

Nemzetközi és hazai példák, kutatások bizonyítják (lásd például Kuti, Bedő, 2018), hogy egyetemi-hallgatói vállalkozói ökoszisztéma fejlesztése fontos szerepet játszik a hallgatói vállalkozási szándék kialakításában és a vállalkozások tényleges elindításában. A vállalkozási ökoszisztéma fogalmát nem könnyü meghatározni, talán még nehezebb egy olyan működőképes formáját megvalósítani, amely igazodik a felsőoktatási intézmény sajátosságaihoz és figyelembe veszi a tágabb gazdasági és társadalmi környezetnek a hallgatókra gyakorolt hatását.

Vissza-visszatérő kérdés a pénzügyi támogatás ügye. A felsőoktatási intézményekben jelenleg korlátozottan állnak rendelkezésre erőforrások a hallgatók vállalkozási terveinek kialakítására és megvalósítására, ráadásul a kutatási eredmények nem támasztják alá a pénzügyi források meghatározó szerepét a vállalkozásokkal összefüggő döntés meghozatalában.

A Budapesti Gazdasági Egyetem hallgatói körében végzett felmérések elemzései azt mutatják, hogy az intézmény hallgatóinak karrier elképzelései, a vállalkozó hallgatók aránya némileg magasabb az országos átlagnál, de nem mutat érdemi eltérést. Létezik azonban egy olyan hallgatói csoport az egyetemen belül, amely a speciális képzési formának köszönhetően nagyobb vállalkozási szándékot és tényleges vállalkozói tevékenységet mutat, mint az intézményi és az országos átlag A Team Academy hallgatóinak statisztikái egyértelműen vállalkozásösztönzési sikerként könyvelhetôk el, ugyanakkor a programba bevont hallgatók száma jelenleg nagyon alacsony. A kérdés itt tehát az, hogy hogyan lehetne a TA jó gyakorlatait szélesebb körre alkalmazhatóvá tenni. Elemzéseink fontos korlátja, hogy a GUESS kutatás keretében csak trendadatok állnak rendelkezésre, nem pedig hallgatói panelek. Az adatbázisok összetételében (nemek, 
képzési területek stb. szerint) ugyanakkor nincsenek érdemi különbségek, így a megfigyelhető változásokat az időbeli eltérésnek tulajdonítjuk.

Célunk a tanulmány keretében az volt, hogy párhuzamot vonjunk a BGE vállalkozásösztönzésre irányuló erőfeszítései és a hallgatói statisztikák között, ugyanakkor az eltelt 10 év történései miatt elképzelhetetlen az egyes okok hatásainak elkülönítése. Így ekeretek között arra vállalkoztunk, hogy a statisztikák bemutatása után ezeket az okokat beazonosítsuk és ismertessük.

A téma jobb megértése érdekében hallgatói interjúk lefolytatására lesz szükség a jövőben, melyek képesek lehetnek jobban megvilágítani a hallgatói elképzelések és az egyetemi erőfeszítések közötti közvetlen kapcsolatot.

\section{FELHASZNÁLT IRODALOM}

Farkas Szilveszter - Gubik S. Andrea (2013): Az egyetemi-főiskolai hallgatók vállalkozói attitűdkutatásának módszertani sajátosságai. Statiszztikai Szemle, 91 (10) pp. 993-1012.

Ferincz Adrienn - Szabó Zsolt Roland (2012): Z generáció hatása a munkaadói szervezetekre. Munkaügyi Szemle, 56 (2), pp 88-93.

Gubik S. Andrea (2013): A magyar hallgatók vállalkozásindító szándékát befolyásoló tényezők modellje: Ajzen tervezett magatartás elméletének kiterjesztése. Vezetéstudomány, 44 (7-8) pp. 18-29.

Gubik S. Andrea - Farkas Szilveszter (2014): Entrepreneurial Activity of Hungarian Students. In: Alexandra Vécsey (szerk.): Management, Enterprise and Benchmarking - In the 21 st Century: Volume of Management. Budapest: Keleti Károly Faculty of Business and Management, Óbuda University, pp. $125-140$.

Gubik S. Andrea - Farkas Szilveszter (2016): A karriermotívumok változásának hatásai a magyarországi hallgatók vállalkozásindítási elképzeléseinek alakulására. Vęetéstudomány, 47(3) pp. 46-55.

Gubik S. Andrea - Farkas Szilveszter (2017): A felsőoktatási intézmények szerepe a hallgatók vállalkozási hajlandóságának alakításában. In: Veresné, Somosi Mariann; Lipták, Katalin (szerk.) „Mérleg és Kibiváasoke” X. Nemzetteözi Tudományos Konferencia = „Balance and Challenges” X. International Scientific Conference: Konferencia kiadvány: A közgazdászképzés elindításának 30. évfordulója alkalmából. Miskolc-Egyetemváros, Magyarország: Miskolci Egyetem Gazdaságtudományi Kar, (2017) pp. 600-612.

Isenberg, D. J. (2011): Introducing the Entrepreneurship Ecosystem: Four Defining Characteristics. $\quad \underline{h t t p s: / / w w w . f o r b e s . c o m / s i t e s / d a n i s e n b e r g / 2011 / 05 / 25 / i n t r o d u c i n g-t h e-~}$ entrepreneurship-ecosystem-four-defining-characteristics/\#3d1700cc5fe8

Kuti Mónika - Bedő Zsolt (2016): Az egyetemi vállalkozói ökoszisztémába ágyazott közösségi finanszírozás. Vęetéstudomány, 47 (2) pp 45-52

Kuti, Mónika - Bedő, Zsolt (2018) Az egyetemi központú vállalkozói ökoszisztéma és a közösségi finanszírozás kapcsolata. Vezetéstudomány - Budapest Management Review, 49 (2). pp. 45-52. DOI https://doi.org/10.14267/VEZTUD.2018.02.05

Lerf, A. (2014): Gondolatok a digitális bennszülöttek világáról. Magyar Coachš̨emle, 3 (1) pp. 14 19.

Lüthje, C. - Franke, N. (2002): Fostering entrepreneurship through university education and training: Lessons from Massachusetts Institute of Technology. European Academy of 
Management, 2nd Annual Conference on Innovative Research in Management, 2002. május 911.,

Stockholm

http:/ / citeseerx.ist.psu.edu/viewdoc/download?doi=10.1.1.203.2530\&rep=rep1\&type $=$ pdf

Morris, M. H. - Shirokova, G. - Tsukanova, T. (2017): Student entrepreneurship and the university ecosystem: a multi-country empirical exploration. European Journal of International Management, 11 (1) pp 65-85. https://doi.org/10.1504/EJIM.2017.081251

Nabi, G. - Walmsley, A. - Liñán, F. - Akhtar, I. - Neame, Ch. (2016): Does entrepreneurship education in the first year of higher education develop entrepreneurial intentions? The role of learning and inspiration, Studies in Higher Education, 43 (3) pp 452-467. http://dx.doi.org/10.1080/03075079.2016.1177716

Richert, J. - Schiller, R. (1994): Hocbschulabsolventen als Existenægründer. Report of the "Deutsche Ausgleichsbank" for the Federal Ministry of Education and Science in Germany, Bonn.

Rideout, E. - Gray, D. (2013): Does entrepreneurship education really work? A review and methodological critique of the empirical literature on the effects of university-based entrepreneurship education. Journal of Small Business Management, 51 (3), pp. 329-351. https://doi.org/10.1111/jsbm.12021

Schot, T. - Kew, P. - Cheraghi, M. (2015): Future Potential. A GEM perspective on youth entrepreneurship 2015. http://www.innovacion.gob.cl/wp-content/uploads/2015/08/gem-2015-youth-report1436523546.pdf

Schrör, H. (2006): The profile of the successful entrepreneur. Results of the survey 'Factors of Business Success'. Statistics in focus 29/2006, Eurostat

Szerb László (2017): A vállalkozói ökoszisztéma Magyarországon a 2010-es években. Helyzetértékelés és szakpolitikai javaslatok. Vez̨etéstudomány, 48. (6-7.) DOI: 10.14267/VEZTUD.2017.06.01

Tari Annamária (2010): Y generáció. Jaffa Kiadó, Budapest

Tasi, P. - Zsigmond, Sz. (2014): A comparative study between a learning-by-doing based educational model and entrepreneurial skills. ICERI2014 Proceedings 7th International Conference of Education, Research and Innovation Seville, Spain. 17-19 November, 2014. ISBN: 978-84-617-24840/ISSN: 2340-1095 Publisher: IATED 
${ }^{18}$ 这 57
BGE 